FOR

\title{
Addition of Sulfur-Hydrogen Bonds Across Electron-Deficient Olefins Catalyzed by Well-Defined Copper(I) Thiolate Complexes
}

Samuel A. Delp, ${ }^{\dagger}$ Colleen Munro-Leighton, ${ }^{\dagger}$ Laurel A. Goj, ${ }^{\dagger}$ Magaly A. Ramírez, ${ }^{\dagger}$ T. Brent Gunnoe, ${ }^{* \dagger}$ Jeffrey L. Petersen ${ }^{\ddagger}$ and Paul D. Boyle ${ }^{\dagger}$

${ }^{\dagger}$ Department of Chemistry, North Carolina State University, Raleigh, North Carolina 27695-8204, and ${ }^{\ddagger}$ C. Eugene Bennett Department of Chemistry, West Virginia University, Morgantown, West Virginia 26506-6045 
General Methods. All procedures were performed under an inert atmosphere in a nitrogen-filled glovebox or using standard Schlenk techniques. Glovebox purity was maintained by periodic nitrogen purges and was monitored by an oxygen analyzer $\left\{\mathrm{O}_{2}(\mathrm{~g})\right.$ $<15 \mathrm{ppm}$ for all reactions $\}$. Benzene, toluene and tetrahydrofuran were purified by distillation over sodium/benzophenone. Pentane was distilled over sodium prior to use. Hexanes were purified by passage through a column of activated alumina. Methyl acrylate was washed with aqueous $\mathrm{NaOH}$, dried over $\mathrm{CaCl}_{2}$ and vacuum distilled. Acrylonitrile was washed with dilute $\mathrm{H}_{2} \mathrm{SO}_{4}$, followed by aqueous $\mathrm{Na}_{2} \mathrm{CO}_{3}$, shaken over $4 \AA$ molecular sieves and then distilled. Methyl vinyl ketone was degassed via three freeze-pump-thaw cycles. Benzene- $d_{6}$ was degassed via three freeze-pump-thaw cycles and stored under a dinitrogen atmosphere over $4 \AA$ molecular sieves. ${ }^{1} \mathrm{H}$ and ${ }^{13} \mathrm{C}$ NMR spectra were acquired using a Varian Mercury $400 \mathrm{MHz}$ or a Varian Mercury $300 \mathrm{MHz}$ spectrometer (operating frequencies for ${ }^{13} \mathrm{C}$ NMR spectra were 100 and $75 \mathrm{MHz}$, respectively) and referenced to tetramethylsilane using residual proton signals of the deuterated solvents or the ${ }^{13} \mathrm{C}$ resonances of the deuterated solvents. IR spectra were obtained on a Mattson Genesis II spectrometer as thin films on a $\mathrm{KBr}$ plate. Electron ionizing (EI) mass spectrometry was carried out using a JEOL (Tokyo, Japan) HX110HF high resolution mass spectrometer at the North Carolina State University Mass Spectrometry Laboratory using perfluorokerosene ions as a reference standard. (IPr)Cu(Me), (SIPr)Cu(Me), and (IMes)Cu(Me) were prepared according to published procedures. ${ }^{1-3}$ All other reagents were used as purchased from commercial sources. Some of the hydrothiolation products and characterization data have been previously reported: $\quad 3$-(phenylthio)propionitrile, ${ }^{4} \quad 4$-(phenylthio)butan-2-one, ${ }^{5}$ methyl 3 - 
(phenylthio)propanoate, ${ }^{6}$

(benzylmercapto)propionitrile, ${ }^{8} \quad$ 3-(benzylmercapto)cyclohexenone, ${ }^{9}$ and 4 -methyl-4(phenylthio)-2-pentanone. ${ }^{10}$

(IPr)Cu(SPh) (1). To a round bottom flask charged with (IPr)Cu(Me) $(0.138 \mathrm{~g}$, $0.30 \mathrm{mmol})$ and $5 \mathrm{~mL}$ of benzene, benzene thiol $(0.151 \mathrm{~mL}, 1.48 \mathrm{mmol})$ was added. After stirring for 5 minutes, the solvent volume was reduced approximately by half in vacuo, and hexanes $(10 \mathrm{~mL})$ were added to precipitate a white solid. The solid was collected by vacuum filtration and washed with 2 x $5 \mathrm{~mL}$ hexanes (0.131 g, 79\%). Crystals were grown by layering a concentrated toluene solution of $\mathbf{1}$ with pentane. ${ }^{1} \mathrm{H}$ NMR $\left(\mathrm{C}_{6} \mathrm{D}_{6}, \delta\right)$ : 7.26-7.18 (overlapping multiplets, $4 \mathrm{H}$, -SPh and para-Ph of IPr), 7.06 (t, $4 \mathrm{H},{ }^{3} J_{\mathrm{HH}}=8 \mathrm{~Hz}$, meta-Ph of IPr), 6.88-6.81 (m, 3H, -SPh), 6.26 (s, 2H, NCH), 2.57 (sept, $\left.{ }^{3} J_{\mathrm{HH}}=7 \mathrm{~Hz}, 4 \mathrm{H}, \mathrm{CH}\left(\mathrm{CH}_{3}\right)_{2}\right), 1.33\left(\mathrm{~d},{ }^{3} J_{\mathrm{HH}}=7 \mathrm{~Hz}, 12 \mathrm{H}, \mathrm{CH}\left(\mathrm{CH}_{3}\right)_{2}\right), 1.07\left(\mathrm{~d},{ }^{3} J_{\mathrm{HH}}=7 \mathrm{~Hz}\right.$, 12H, $\left.\mathrm{CH}\left(\mathrm{CH}_{3}\right)_{2}\right) .{ }^{13} \mathrm{C}\left\{{ }^{1} \mathrm{H}\right\}$ NMR $\left(\mathrm{C}_{6} \mathrm{D}_{6}, \delta\right) 182.8(\mathrm{NCN}), 147.2,146.2,135.2,134.1$, 131.1, 124.8, 121.4 (IPr aryl and sulfido aryl; one resonance due to aryl rings not observed, presumably due to coincidental overlap.), $122.9(\mathrm{NCH}), 29.6\left(\mathrm{CH}_{(}\left(\mathrm{CH}_{3}\right)_{2}\right), 25.3$ $\left(\mathrm{CH}\left(\mathrm{CH}_{3}\right)_{2}\right)$, $24.3\left(\mathrm{CH}\left(\mathrm{CH}_{3}\right)_{2}\right)$. Anal. Calcd. for $\mathrm{C}_{33} \mathrm{H}_{41} \mathrm{CuN}_{2} \mathrm{~S}$ : C, 70.60; H, 7.36; N, 4.99. Found: C, 69.97; H, 7.33; N, 4.92.

(IPr) $\mathbf{C u}\left(\mathbf{S C H}_{2} \mathbf{P h}\right)$ (2). To a round bottom flask charged with (IPr)Cu(Me) (0.114 g, $0.244 \mathrm{mmol})$ and $5 \mathrm{~mL}$ of benzene, benzyl mercaptan $(0.145 \mathrm{~mL}, 1.23 \mathrm{mmol})$ was added. After stirring for 30 minutes, the solvent volume was reduced approximately by half in vacuo, and hexanes were added to precipitate a white solid. The solid was collected by vacuum filtration $(0.118 \mathrm{~g}, 84 \%)$. Crystals were grown by layering a concentrated benzene solution of 2 with pentane. ${ }^{1} \mathrm{H}$ NMR $\left(\mathrm{C}_{6} \mathrm{D}_{6}, \delta\right)$ 7.26-7.16, 7.12- 
7.03 (overlapping multiplets, $11 \mathrm{H}$ total, IPr aryl and thiolate phenyl), 6.23 (s, $2 \mathrm{H}, \mathrm{NCH}$ ), 3.81 (br s, 2H, SCH $2 \mathrm{Ph}$ ), 2.58 (sept, $\left.{ }^{3} J_{\mathrm{HH}}=7 \mathrm{~Hz}, 4 \mathrm{H}, \mathrm{CH}\left(\mathrm{CH}_{3}\right)_{2}\right), 1.37\left(\mathrm{~d},{ }^{3} J_{\mathrm{HH}}=7 \mathrm{~Hz}\right.$, 12H, $\left.\mathrm{CH}\left(\mathrm{CH}_{3}\right)_{2}\right), 1.08\left(\mathrm{~d},{ }^{3} \mathrm{~J}_{\mathrm{HH}}=7 \mathrm{~Hz}, 12 \mathrm{H}, \mathrm{CH}\left(\mathrm{CH}_{3}\right)_{2}\right) .{ }^{13} \mathrm{C}\left\{{ }^{1} \mathrm{H}\right\} \mathrm{NMR}\left(\mathrm{C}_{6} \mathrm{D}_{6}, \delta\right) 183.3$ (NCN), 148.8, 146.2, 135.4, 131.0, 129.2, 125.2, 124.7 (IPr aryl and thiolate aryl; one resonance due to aryl rings not observed, presumably due to coincidental overlap), 122.7 (NCH), $30.5\left(\mathrm{SCH}_{2} \mathrm{Ph}\right), 29.5\left(\mathrm{CH}\left(\mathrm{CH}_{3}\right)_{2}\right), 25.5\left(\mathrm{CH}\left(\mathrm{CH}_{3}\right)_{2}\right), 24.3\left(\mathrm{CH}\left(\mathrm{CH}_{3}\right)_{2}\right.$. The instability of the complex precluded satisfactory elemental analysis. HR-MS (EI) calculated (theoretical): [(IPr)Cu( $\left.\left.\mathrm{SCH}_{2} \mathrm{Ph}\right)\right]^{+} 574.25$ (574.24).

(SIPr)Cu(SPh) (3). To a round bottom flask charged with (SIPr)Cu(Me) $(0.100$ g, $0.21 \mathrm{mmol})$ and $5 \mathrm{~mL}$ of benzene, benzene thiol $(22 \mu \mathrm{L}, 0.21 \mathrm{mmol})$ was added, and the solution stirred for 15 minutes. The solvent volume was reduced approximately by half in vacuo, and hexanes were added to yield a white solid. The solid was collected and dried $(0.100$ g, 83\%). Crystals were grown by layering a concentrated benzene solution of 3 with pentane. ${ }^{1} \mathrm{H}$ NMR $\left(\mathrm{C}_{6} \mathrm{D}_{6}, \delta\right) 7.20$ (br m, 2H, para-CH of SIPr ligand,), 7.107.04 (overlapping multiplets, 6H, meta-SPh and meta-aryl of SIPr ligand), 6.88-6.78 (overlapping multiplets, 3H, para-SPh and ortho-SPh), 3.18 (s, 4H, $\mathrm{NCH}_{2}$ ), 2.98 (sept, $\left.{ }^{3} J_{\mathrm{HH}}=7 \mathrm{~Hz}, 4 \mathrm{H}, \mathrm{CH}\left(\mathrm{CH}_{3}\right)_{2}\right), 1.42\left(\mathrm{~d},{ }^{3} J_{\mathrm{HH}}=7 \mathrm{~Hz}, 12 \mathrm{H}, \mathrm{CH}\left(\mathrm{CH}_{3}\right)_{2}\right), 1.18\left(\mathrm{~d},{ }^{3} J_{\mathrm{HH}}=7\right.$ $\left.\mathrm{Hz}, 12 \mathrm{H}, \mathrm{CH}\left(\mathrm{CH}_{3}\right)_{2}\right) .{ }^{13} \mathrm{C}\left\{{ }^{1} \mathrm{H}\right\}$ NMR (DMSO- $\left.d_{6}, \delta\right) 200.6$ (NCCu), 146.2, 144.2, 134.2, 131.4, 129.1, 126.9, 123.9, 120.4 (SIPr and thiolate aryl), $\left.53.5\left(\mathrm{NCH}_{2}\right), 28.2\left(\mathrm{CH}_{(\mathrm{CH}}\right)_{2}\right)$, 25.2 $\left(\mathrm{CH}\left(\mathrm{CH}_{3}\right)_{2}\right)$, $23.6\left(\mathrm{CH}\left(\mathrm{CH}_{3}\right)_{2}\right)$. Anal. Calcd. for $\mathrm{C}_{33} \mathrm{H}_{43} \mathrm{CuN}_{2} \mathrm{~S}:$ C, 70.36: H, 7.69: N, 4.97. Found: C, 69.97; H, 7.77; N, 4.97.

(SIPr)Cu(SCH $2 \mathbf{P h})$ (4). To a round bottom flask charged with (SIPr)Cu(Me) (0.047 g, $0.09 \mathrm{mmol})$ and $5 \mathrm{~mL}$ of benzene, benzyl mercaptan $(12 \mu \mathrm{L}, 0.09 \mathrm{mmol})$ was 
added, and the solution was stirred for 15 minutes. The solvent volume was reduced approximately by half in vacuo, and hexanes were added to yield a white solid. The solid was collected and dried (0.048 g, 83\%). Crystals were grown by layering a concentrated benzene solution of 4 with pentane. ${ }^{1} \mathrm{H}$ NMR $\left(\mathrm{C}_{6} \mathrm{D}_{6}, \delta\right)$ 7.24-7.13, 7.12-7.00 (overlapping multiplets, $11 \mathrm{H}$ total, $\mathrm{SIPr}$ aryl and $\mathrm{SCH}_{2} \mathrm{Ph}$ phenyl), 3.67 (s, $2 \mathrm{H}, \mathrm{SCH}_{2} \mathrm{Ph}$ ), 3.15 (s, 4H, NCH$)_{2}, 2.97$ (sept, $\left.{ }^{3} J_{\mathrm{HH}}=6 \mathrm{~Hz}, 4 \mathrm{H}, \mathrm{CH}\left(\mathrm{CH}_{3}\right)_{2}\right), 1.42\left(\mathrm{~d},{ }^{3} J_{\mathrm{HH}}=6 \mathrm{~Hz}, 12 \mathrm{H}\right.$, $\left.\mathrm{CH}\left(\mathrm{CH}_{3}\right)_{2}\right), 1.17\left(\mathrm{~d},{ }^{3} J_{\mathrm{HH}}=6 \mathrm{~Hz}, 12 \mathrm{H}, \mathrm{CH}\left(\mathrm{CH}_{3}\right)_{2}\right) .{ }^{13} \mathrm{C}\left\{{ }^{1} \mathrm{H}\right\}$ NMR $\left(\mathrm{DMSO}-d_{6}, \delta\right) 215.6$ (NCCu), 146.6, 146.2, 134.8, 129.4, 127.7, 127.6, 124.7, 124.3, (SIPr and thiolate aryl), $67.0\left(\mathrm{SCH}_{2} \mathrm{Ph}\right), 53.6\left(\mathrm{NCH}_{2}\right), 28.2\left(\mathrm{CH}\left(\mathrm{CH}_{3}\right)_{2}\right), 25.2\left(\mathrm{CH}\left(\mathrm{CH}_{3}\right)_{2}\right), 23.5\left(\mathrm{CH}\left(\mathrm{CH}_{3}\right)_{2}\right)$. Anal. Calcd. for $\mathrm{C}_{34} \mathrm{H}_{45} \mathrm{CuN}_{2} \mathrm{~S}$ : C, 70.73: H, 7.86: N, 4.85. Found: C, 70.27; H, 7.92; N, 4.87 .

(IMes)Cu(SPh) (5). To a round bottom flask charged with (IMes)CuCl (0.330 g, $0.82 \mathrm{mmol})$ and $20 \mathrm{~mL}$ of benzene, sodium thiophenolate $(0.136 \mathrm{~g}, 1.03 \mathrm{mmol})$ was added. The resulting suspension was stirred for 4 hours and then filtered through Celite. The filtrate volume was reduced until precipitate was observed. Hexanes were added to yield a white solid. The solid was collected by vacuum filtration $(0.173 \mathrm{~g}, 43 \%) .{ }^{1} \mathrm{H}$ NMR $\left(\mathrm{C}_{6} \mathrm{D}_{6}, \delta\right) 7.33$ (br m, 2H, ortho-SPh), 6.92-6.84 (overlapping multiplets, 3H, metaand para-SPh), 6.68 (s, 4H, meta-CH of IMes ligand), 5.96 (s, 2H, NCH), 2.11 (s, 6H, para- $\mathrm{CH}_{3}$ of IMes aryl), 1.90 (s, 12H, ortho- $\mathrm{CH}_{3}$ of IMes aryl). ${ }^{13} \mathrm{C}\left\{{ }^{1} \mathrm{H}\right\}$ NMR $\left(\mathrm{C}_{6} \mathrm{D}_{6}, \delta\right)$ $184.0(\mathrm{NCN}), 147.5$ (thiolate ), 139.0, 136.3, 135.5, 133.9, 129.8, 127.8 (IMes and thiolate phenyl; one resonance due to aryl rings not observed, presumably due to coincidental overlap), $121.4(\mathrm{NCH}), 21.7$ (para- $\mathrm{CH}_{3}$ of IMes aryl), 18.3 (ortho- $\mathrm{CH}_{3}$ of 
IMes aryl). The instability of this complex precluded satisfactory elemental analysis. A ${ }^{1} \mathrm{H}$ NMR spectrum of $\mathbf{5}$ is included as Figure S13 as an indication of sample purity.

(IMes) $\mathbf{C u}\left(\mathbf{S C H}_{2} \mathbf{P h}\right)$ (6). An NMR tube was charged with (IMes)Cu(Cl) $(0.012$ g, $0.03 \mathrm{mmol})$, $\mathrm{LiSCH}_{2} \mathrm{Ph}(0.011 \mathrm{~g}, 0.08 \mathrm{mmol})$, and $\mathrm{C}_{6} \mathrm{D}_{6}$. A ${ }^{1} \mathrm{H}$ NMR spectrum was obtained after one hour. ${ }^{1} \mathrm{H}$ NMR $\left(\mathrm{C}_{6} \mathrm{D}_{6}, \delta\right)$ 7.55-7.00 (overlapping multiplets, $10 \mathrm{H}$, thiolate aryl), 6.68 (s, 4H, meta-aryl of IMes ligand), 5.99 (s, 2H, NCH), 3.69 (bs, 4H, $\mathrm{SCH}_{2}$ ), 2.09 (s, 6H, para- $\mathrm{CH}_{3}$ ), 1.97 (s, 12H, ortho- $\mathrm{CH}_{3}$ ).

Sample catalysis experiment. Reaction of benzenethiol and acrylonitrile with catalytic (IPr)Cu(SPh) (1): An NMR tube was charged with 1 (0.011 g, $0.020 \mathrm{mmol})$, benzenethiol (40.2 $\mu \mathrm{L}, 0.392 \mathrm{mmol})$, acrylonitrile $(24.2 \mu \mathrm{L}, 0.368 \mathrm{mmol})$ and $\mathrm{C}_{6} \mathrm{D}_{6}(0.5$ $\mathrm{mL}$ ) and sealed with a rubber septum. The reaction was monitored periodically by ${ }^{1} \mathrm{H}$ NMR spectroscopy at room temperature. After 3.5 hours, all acrylonitrile was consumed, and formation of 3-(phenylthio)propionitrile was detected. The production of 3(phenylthio)propionitrile was confirmed by removal of solvent followed by an NMR of the resulting residue in $\mathrm{CDCl}_{3}$, which was compared to the previously reported data (see General Methods section above for references to previously reported data for organic compounds). Percent conversion to product was determined to be quantitative by integration of ${ }^{1} \mathrm{H}$ NMR spectra.

Isolation and characterization of 3-methyl-4-(phenylthio)-2-pentanone: To a round bottom flask charged with (IMes) $\mathrm{Cu}(\mathrm{SPh})$ (5) (0.035 g, $0.0608 \mathrm{mmol}$ ), benzenethiol $(150 \mu \mathrm{L}, 1.46 \mathrm{mmol})$ and $3 \mathrm{~mL}$ of benzene, E-3-methyl-3-penten-2-one (166 $\mu \mathrm{L}, 1.48 \mathrm{mmol}$ ) was added, and the solution was stirred for 3 hours at room temperature. The solvent volume was reduced approximately by half in vacuo, and 
hexanes were added to precipitate the catalyst $\mathbf{5}$. The solid was removed by vacuum filtration, and the volatiles were removed in vacuo to yield a colorless oil. The oil was dried under vacuum and isolated (0.239 g, 79\%). ${ }^{1} \mathrm{H}$ NMR spectroscopy revealed the presence of predominantly one product with minor resonances due to a second diastereomer present (> $90 \%$ one diastereomer). ${ }^{1} \mathrm{H}$ NMR $\left(\mathrm{CDCl}_{3}, \delta\right) 7.39(\mathrm{~m}, 2 \mathrm{H}$, phenyl ), 7.24 (m, 3H, phenyl), 3.44 (quint., ${ }^{3} J_{\mathrm{HH}}=7 \mathrm{~Hz}, 1 \mathrm{H}, \mathrm{C}(\mathrm{O}) \mathrm{CH}$ ), 2.65 (quint., ${ }^{3} J_{\mathrm{HH}}$ $=7 \mathrm{~Hz}, 1 \mathrm{H}, \mathrm{S}-\mathrm{CH}), 2.17$ (s, 3H, C(O)CH $\left.\mathrm{CH}_{3}\right), 1.27\left(\mathrm{~d},{ }^{3} \mathrm{~J}_{\mathrm{HH}}=7 \mathrm{~Hz}, 3 \mathrm{H}, \mathrm{C}(\mathrm{O}) \mathrm{CH}-\mathrm{CH}_{3}\right), 1.25$ (d, $\left.{ }^{3} J_{\mathrm{HH}}=7 \mathrm{~Hz}, 3 \mathrm{H}, \mathrm{SCH}-\mathrm{CH}_{3}\right) .{ }^{13} \mathrm{C}\left\{{ }^{1} \mathrm{H}\right\}$ NMR $\left(\mathrm{CDCl}_{3}, \delta\right) 210.6$ (C=O), 134.6 (ipsophenyl), 132.6, 129.1, 127.4 (ortho, meta and para phenyl), $52.3(\mathrm{C}(\mathrm{O}) \mathrm{CH}), 46.5(\mathrm{SCH})$, $30.0\left(\mathrm{C}(\mathrm{O}) \mathrm{CH}_{3}\right), 20.5\left(\mathrm{SCHCH}_{3}\right), 15.0\left(\mathrm{C}(\mathrm{O}) \mathrm{CHCH}_{3}\right)$. Anal. Calcd. for $\mathrm{C}_{12} \mathrm{H}_{16} \mathrm{OS}$ : C, 69.19; H, 7.74. Found: C, 69.25; H, 7.78. 


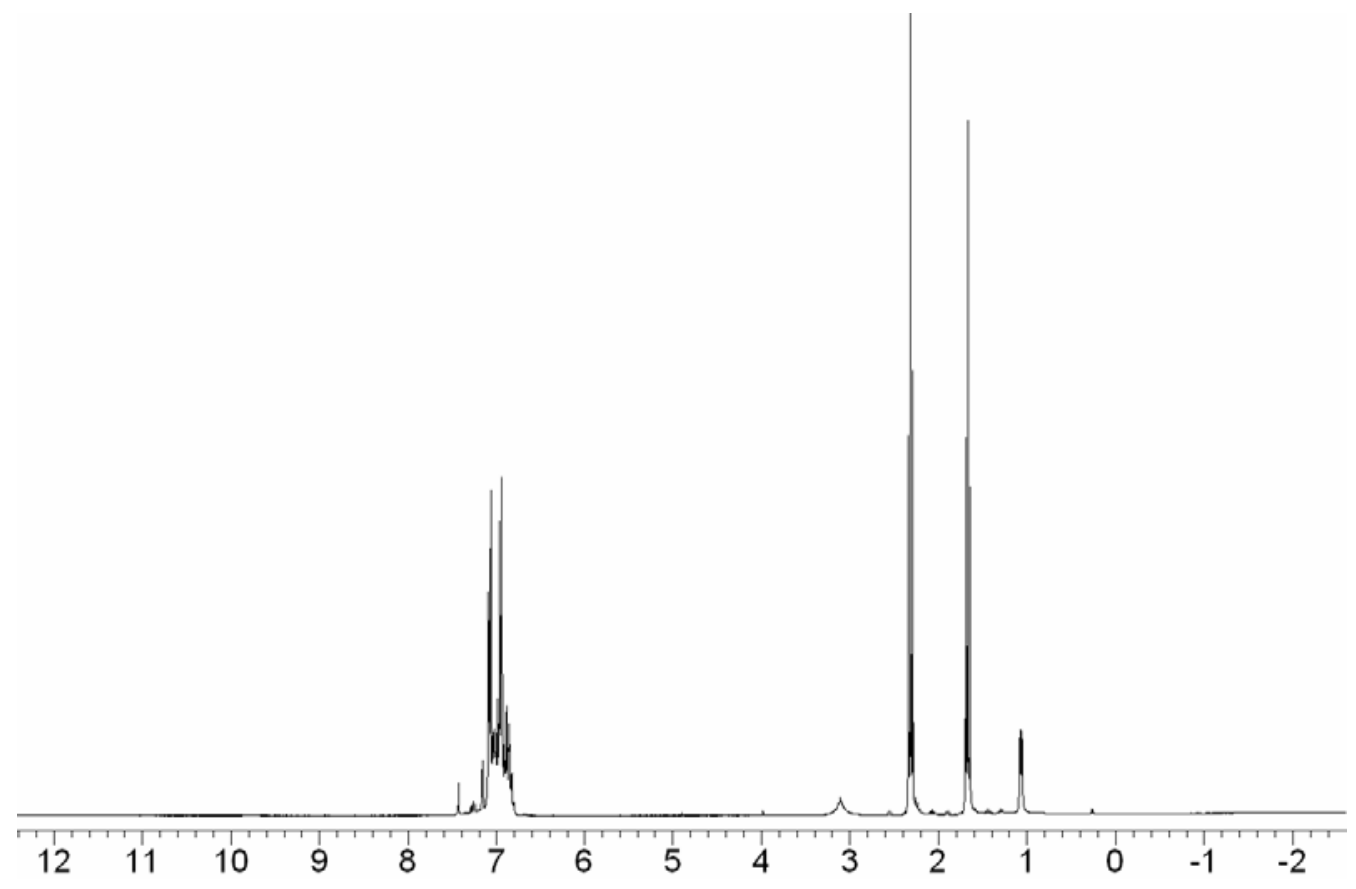

Figure S1. Final ${ }^{1} \mathrm{H}$ NMR of reaction of benzene thiol and acrylonitrile catalyzed by $\mathbf{1}$.

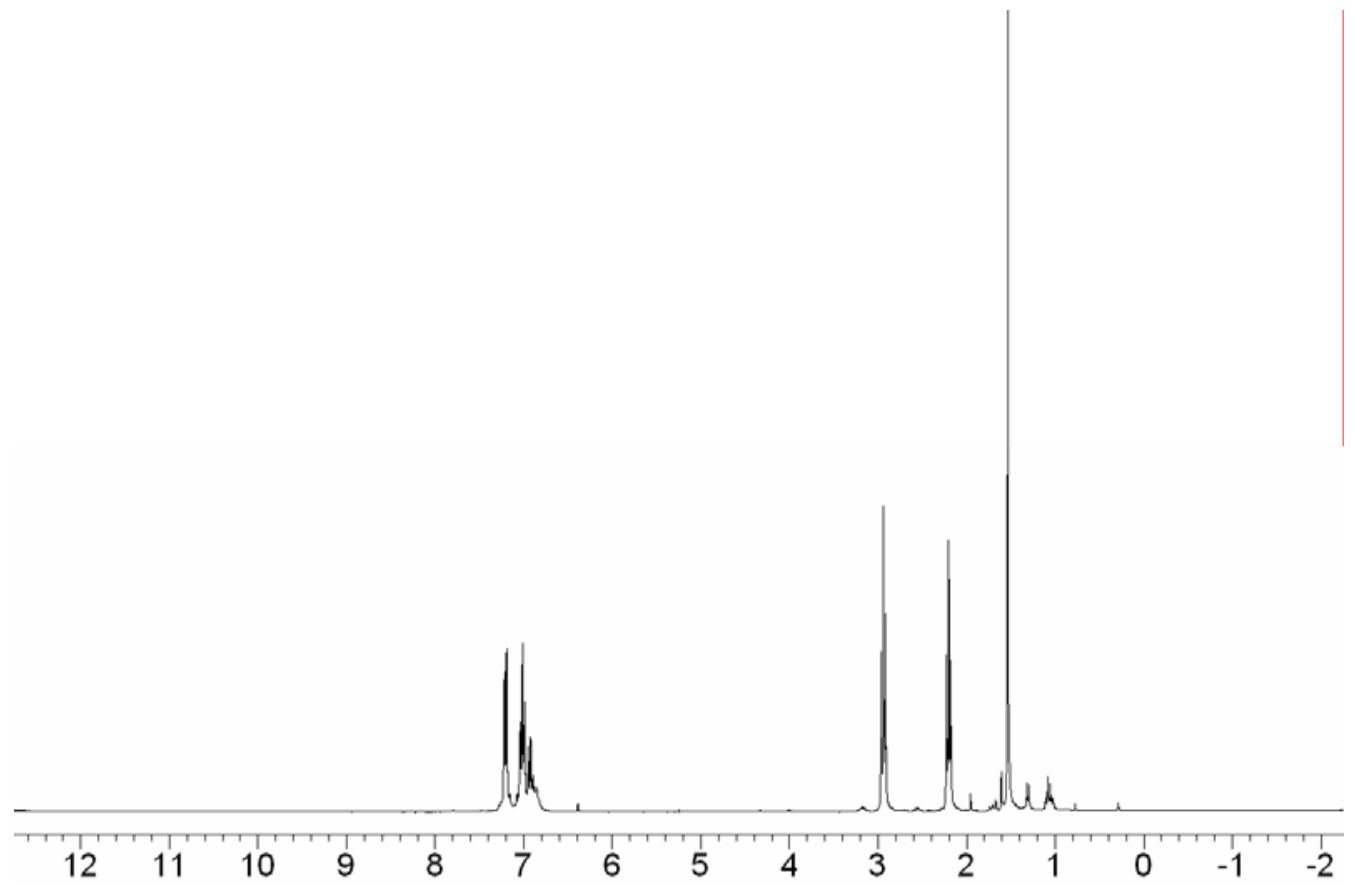

Figure S2. Final ${ }^{1} \mathrm{H}$ NMR of reaction of benzene thiol and methyl vinyl ketone catalyzed by 1 . 


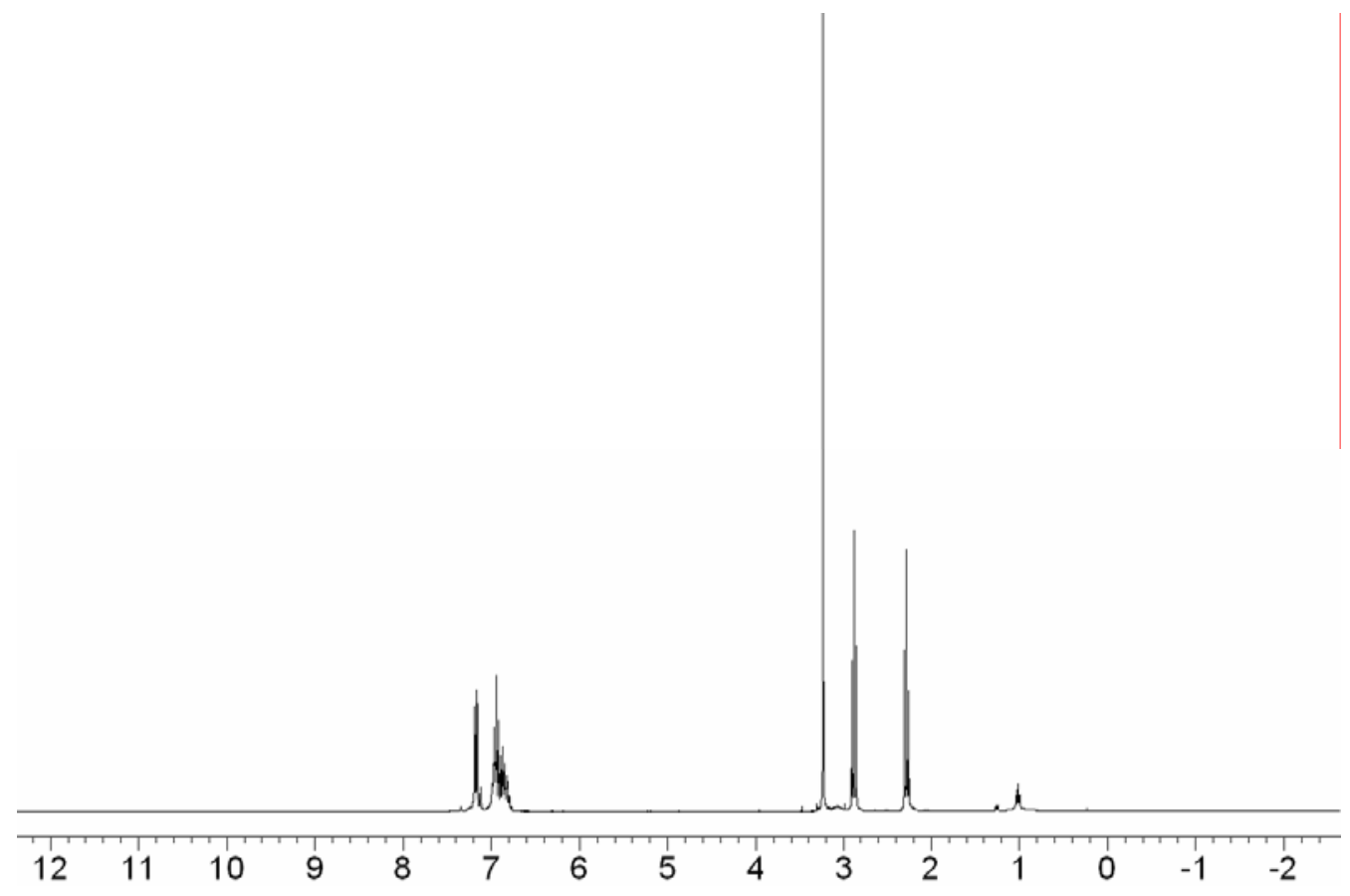

Figure S3. Final ${ }^{1} \mathrm{H}$ NMR of reaction of benzene thiol and methyl acrylate catalyzed by 1.

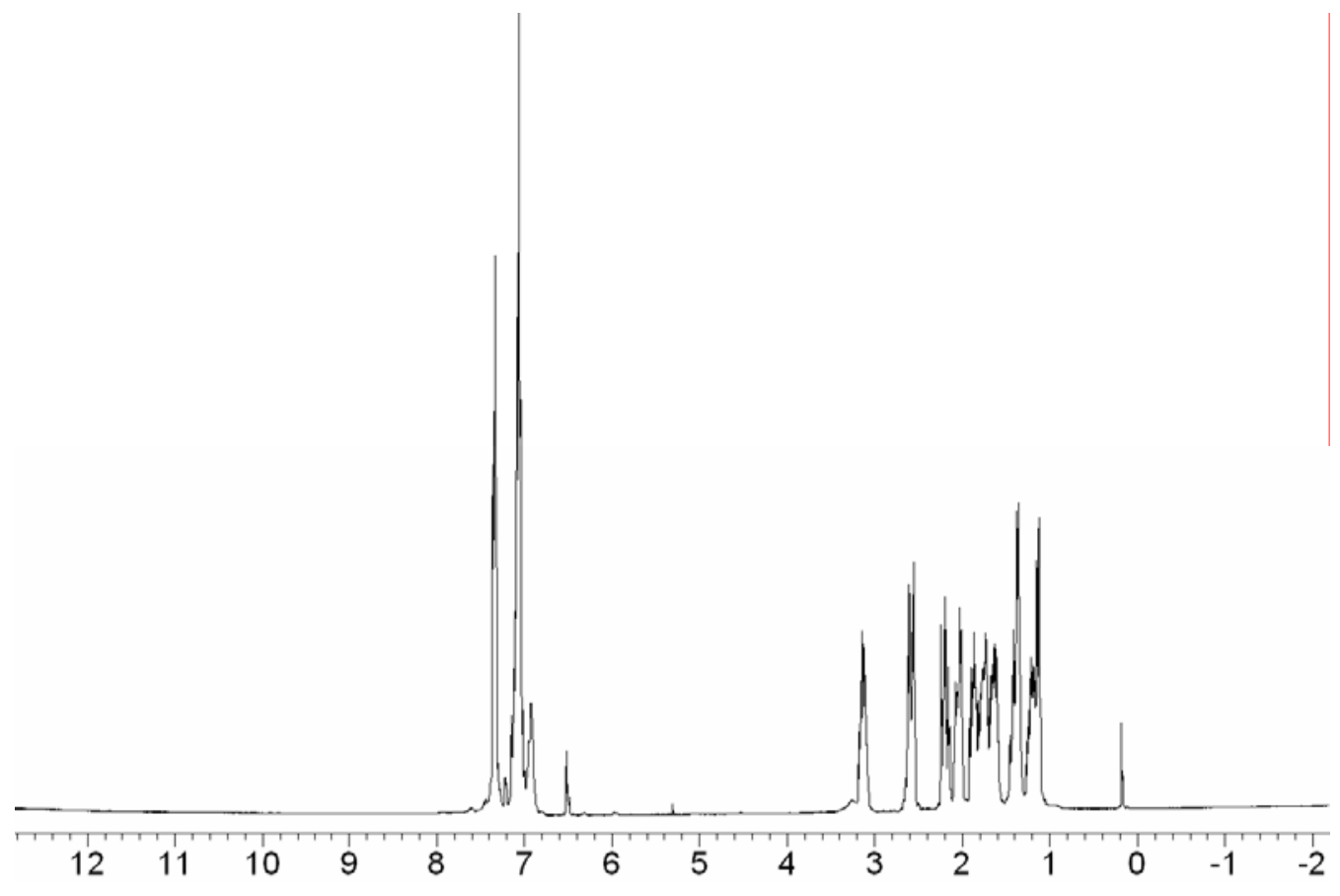

Figure S4. Final ${ }^{1} \mathrm{H}$ NMR of reaction of benzene thiol and cyclohexenone catalyzed by 1. 


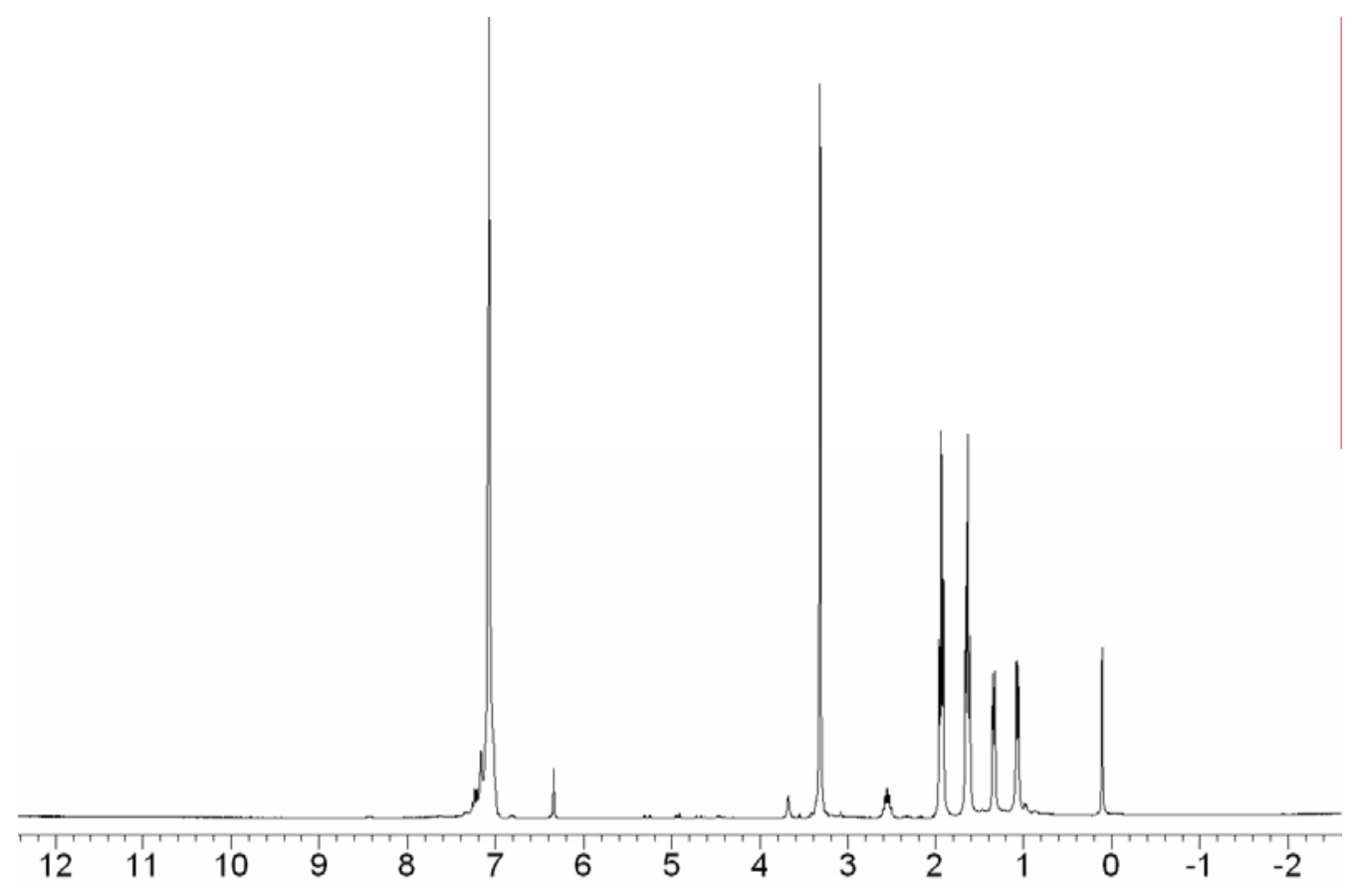

Figure S5. Final ${ }^{1} \mathrm{H}$ NMR of reaction of benzyl mercaptan and acrylonitrile catalyzed by 2.

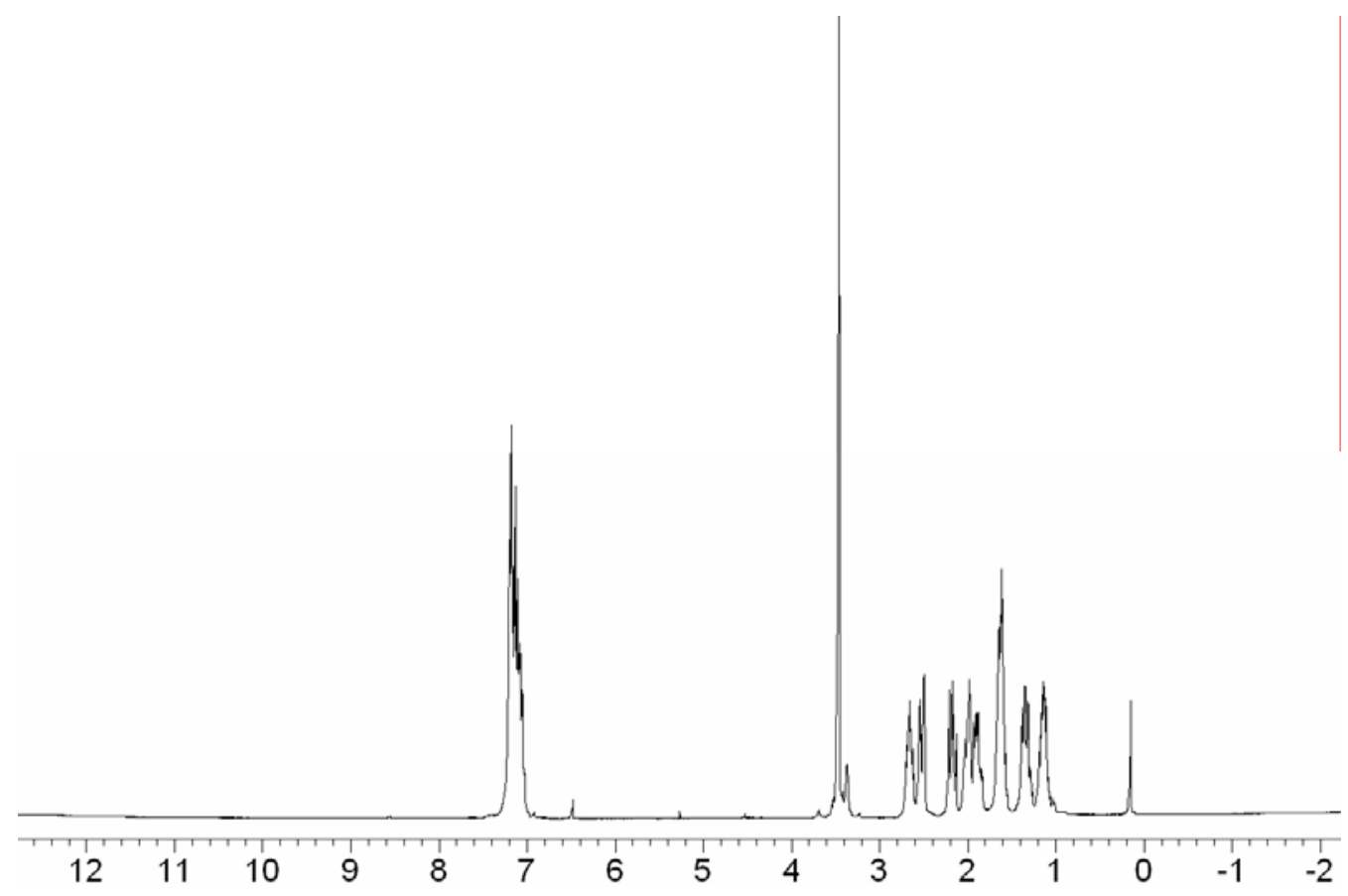

Figure S6. Final ${ }^{1} \mathrm{H}$ NMR of reaction of benzyl mercaptan and cyclohexenone catalyzed by 2 . 


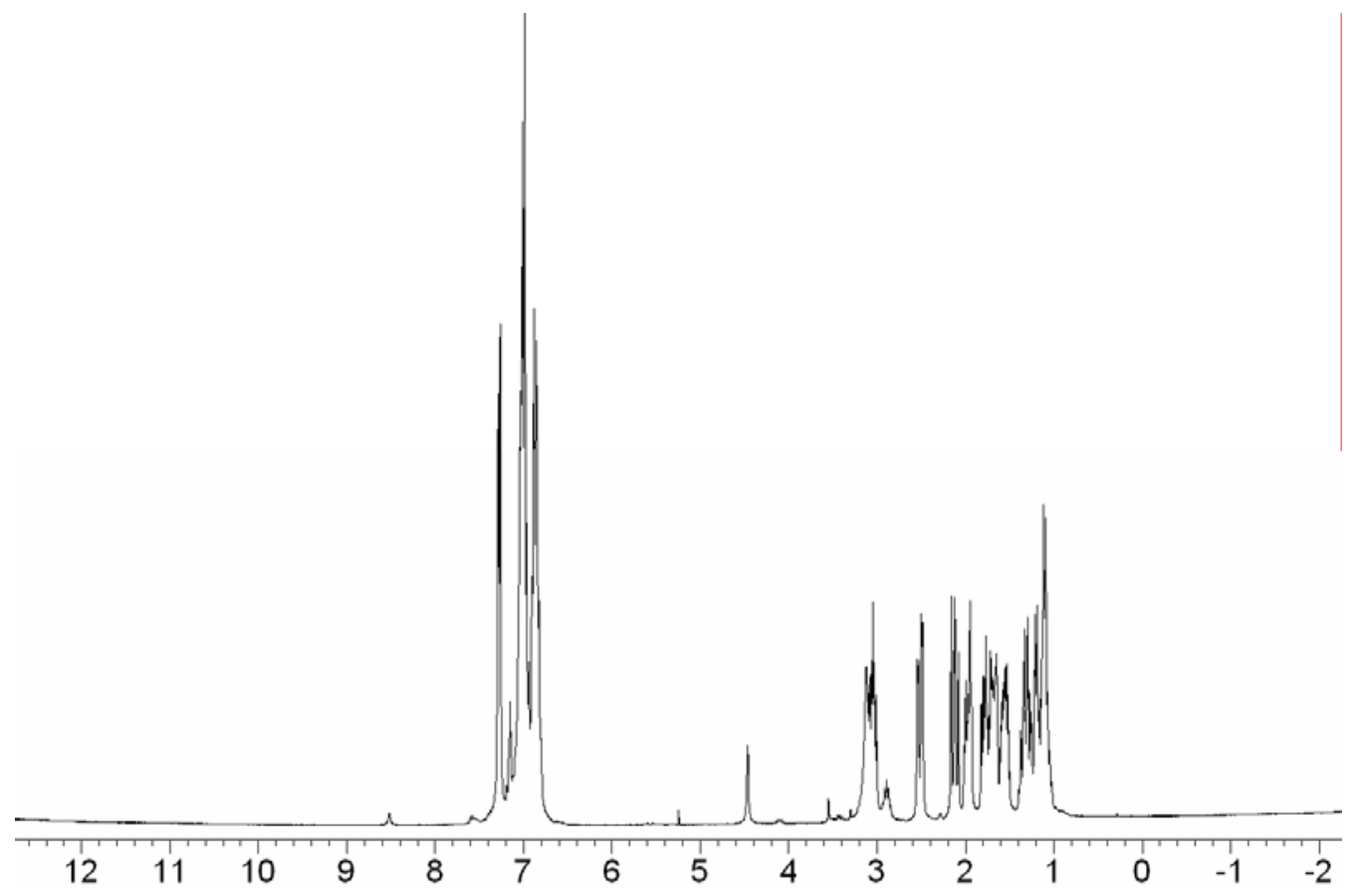

Figure S7. Final ${ }^{1} \mathrm{H}$ NMR of reaction of benzene thiol and cyclohexenone catalyzed by 3.

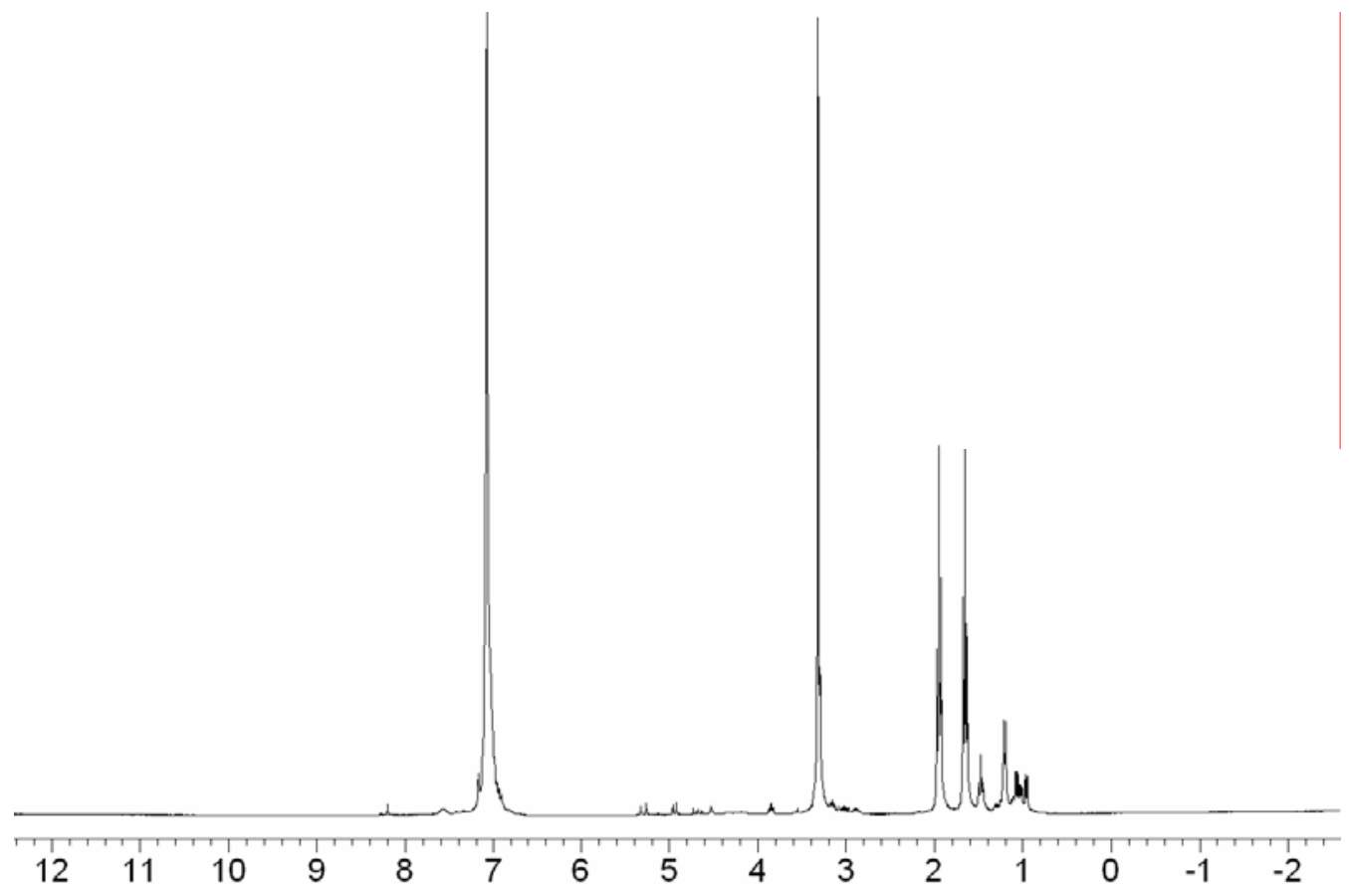

Figure S8. Final ${ }^{1} \mathrm{H}$ NMR of reaction of benzyl mercaptan and acrylonitrile catalyzed by 4. 


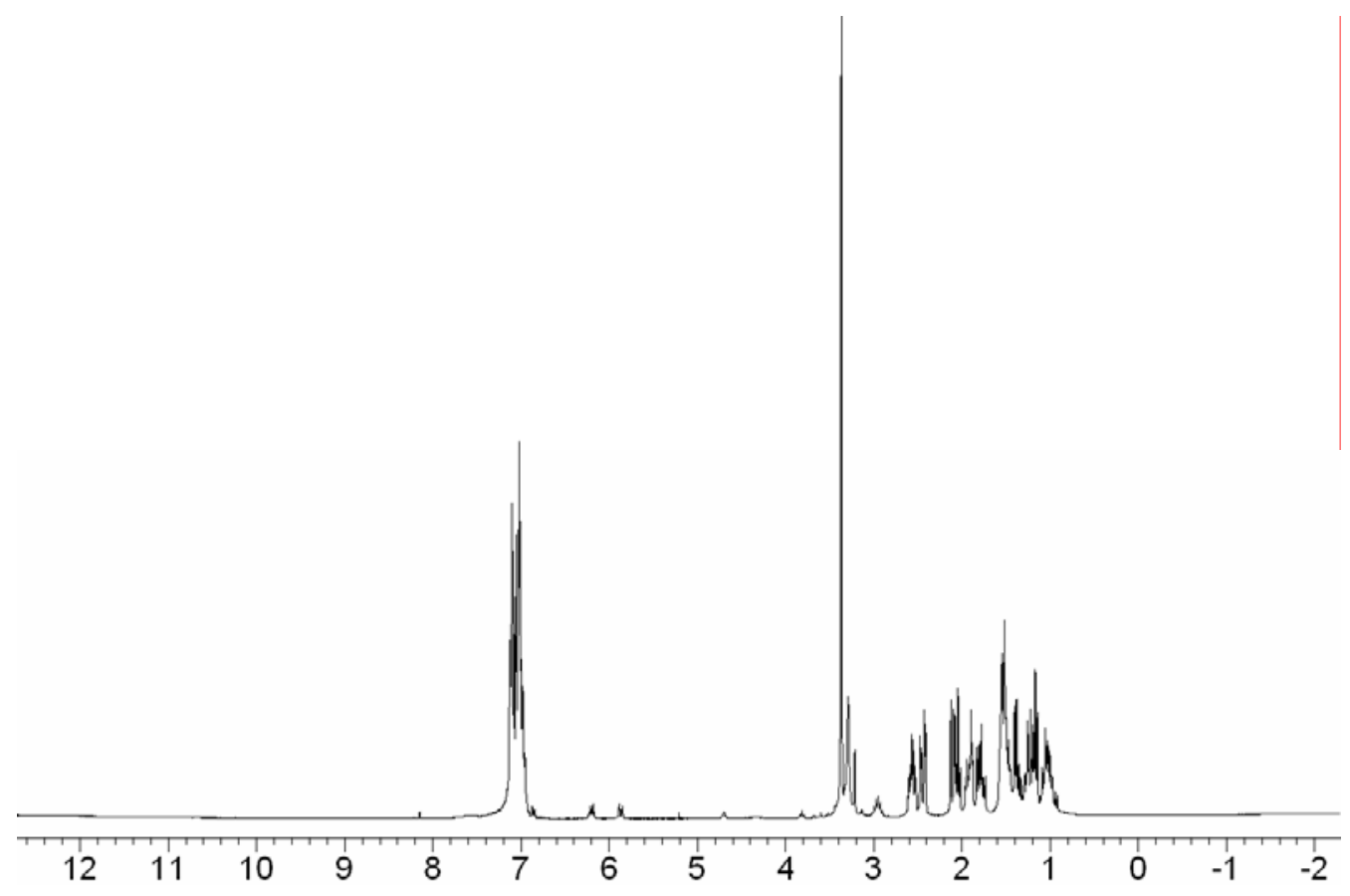

Figure S9. Final ${ }^{1} \mathrm{H}$ NMR of reaction of benzyl mercaptan and cyclohexenone catalyzed by 4 .

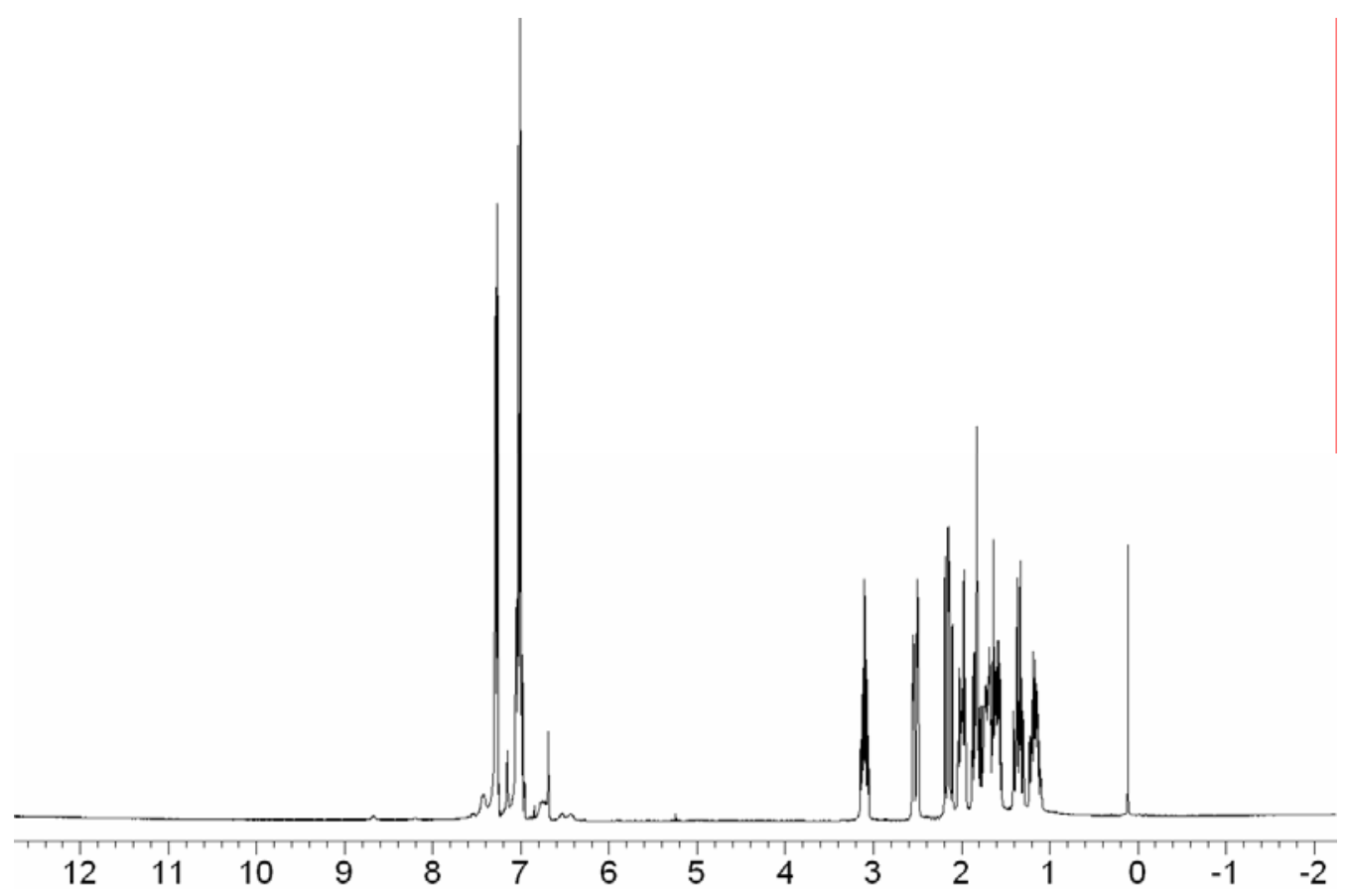

Figure S10. Final ${ }^{1} \mathrm{H}$ NMR of reaction of benene thiol and cyclohexenone catalyzed by 5. 


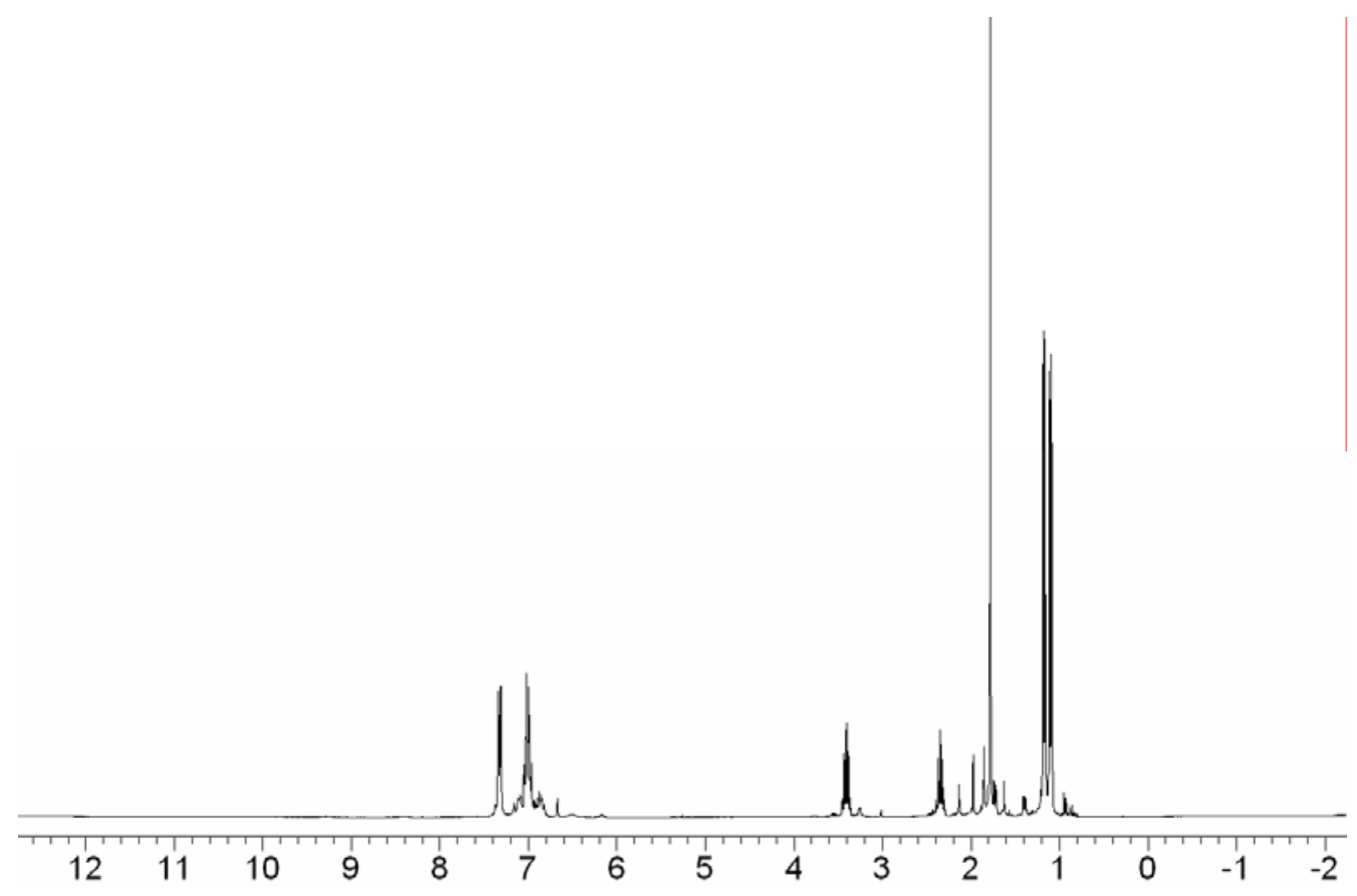

Figure S11. Final ${ }^{1} \mathrm{H}$ NMR of reaction of benene thiol and 3-methyl-3-penten-2-one acrylonitrile catalyzed by $\mathbf{5}$.

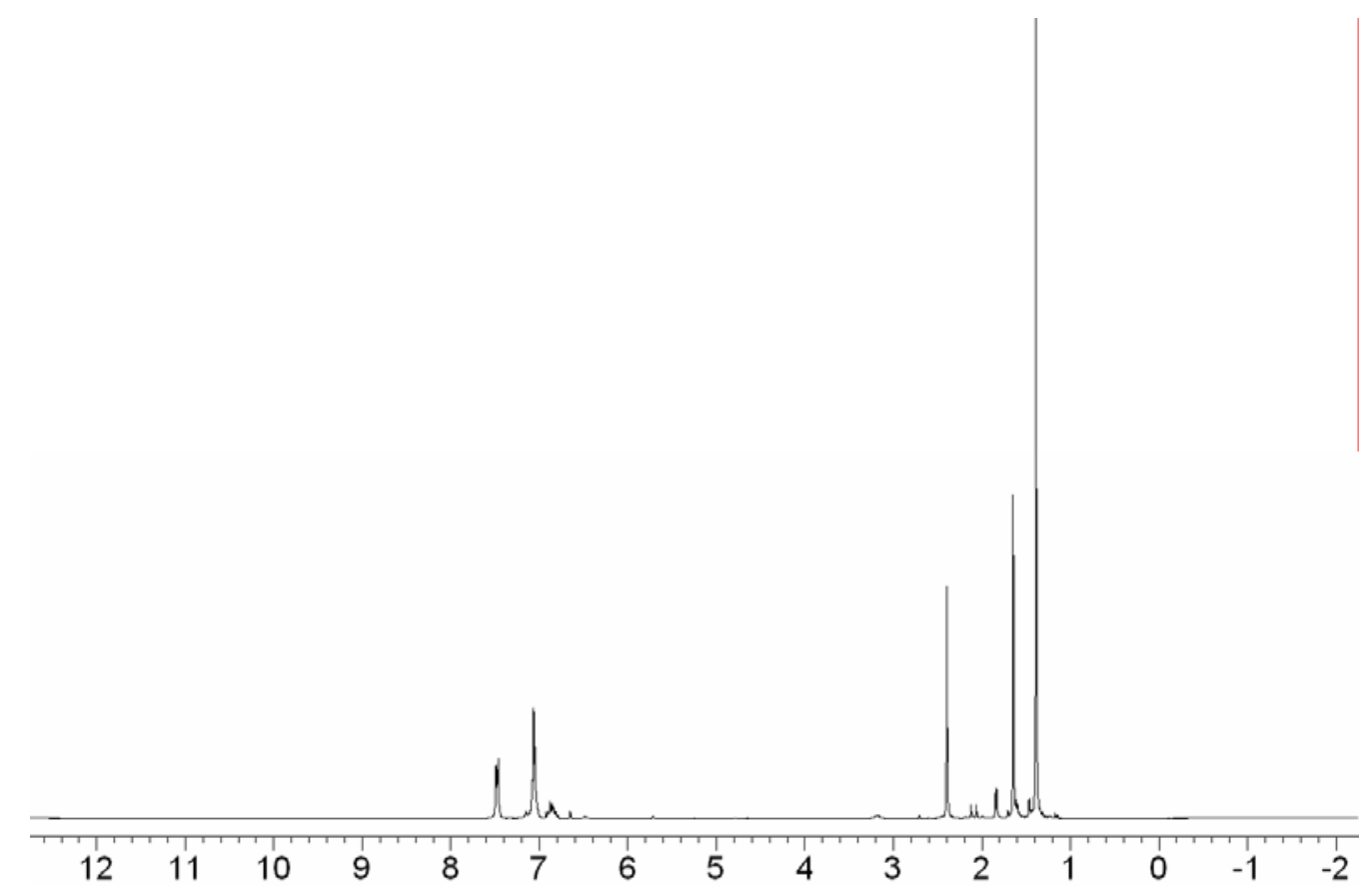

Figure S12. Final ${ }^{1} \mathrm{H}$ NMR of reaction of benene thiol and 4-methyl-3-penten-2-one acrylonitrile catalyzed by 5 . 


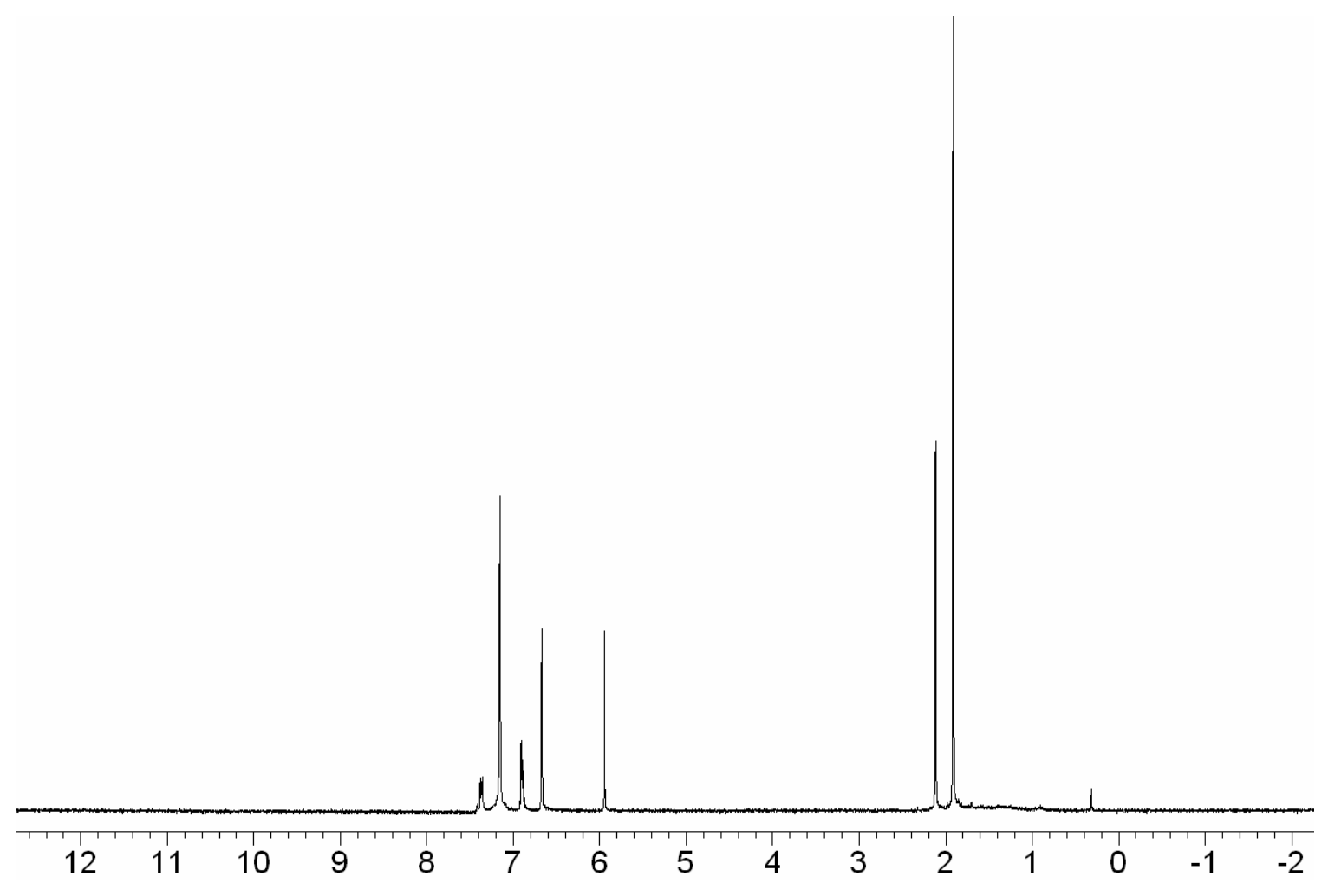

Figure S13. ${ }^{1} \mathrm{H}$ NMR of (IMes)Cu(SPh) (5). 


\section{$\underline{\text { References }}$}

(1) Mankad, N. P.; Gray, T. G.; Laitar, D. S.; Sadighi, J. P., Organometallics 2004, 23, 1191-1193.

(2) Goj, L. A.; Blue, E. D.; Delp, S. A.; Gunnoe, T. B.; Cundari, T. R.; Petersen, J. L., Organometallics 2006, 25, 4097-4104.

(3) Goj, L. A.; Blue, E. D.; Delp, S. A.; Gunnoe, T. B.; Cundari, T. R.; Pierpont, A. W.; Petersen, J. L.; Boyle, P. D., Inorg. Chem. 2006, 45, 9032-9045.

(4) Adams, H.; Anderson, J. C.; Bell, R.; Jones, D. N.; Peel, M. R.; Tomkinson, N. C. O., J. Chem. Soc., Perkin Trans. 1 1998, 3967-3973.

(5) Wabnitz, T. C.; Spencer, J. B., Org. Lett. 2003, 5, 2141-2144.

(6) Al-Awadi, S. A.; Abdallah, A. R.; Dib, H. H.; Ibrahim, A. R.; Al-Awadi, N. A.; El-Dusouqui, O. M. E., Tetrahedron 2005, 61, 5769-5777.

(7) Bandini, M.; Cozzi, P. G.; Giacomini, M.; Melchiorre, P.; Selva, S.; UmaniRonchi, A., J. Org. Chem. 2002, 67, 3700-3704.

(8) Kaptein, B.; Barf, G.; Kellogg, R. M.; Vanbolhuis, F., J. Org. Chem. 1990, 55, 1890-1901.

(9) Sundararajan, G.; Prabagaran, N., Org. Lett. 2001, 3, 389-392.

(10) Spruce, L. W.; Gale, J. B.; Berlin, K. D.; Verma, A. K.; Breitman, T. R.; Ji, X. H.; Vanderhelm, D., J. Med. Chem. 1991, 34, 430-439. 